\title{
FAKTOR-FAKTOR YANG MEMPENGARUHI KEPUTUSAN MAHASISWA DALAM MEMILIH JURUSAN AKUNTANSI PROGRAM S1 DI UNIVERSITAS PENDIDIKAN GANESHA
}

\author{
Komang Winda Suriyani \\ e-mail:\{windasuriyani18@gmail.com, aris herawati@yahoo.co.id,
}

\author{
Jurusan Akuntansi Program S1 \\ Universitas Pendidikan Ganesha \\ Singaraja, Indonesia
}

\begin{abstract}
ABSTRAK
Meningkatnya peminat jurusan akuntansi di berbagai perguruan tinggi membuktikan bahwa ilmu akuntansi dewasa ini semakin digemari. Hal ini menarik untuk dibahas, untuk mengetahui hal-hal yang melatarbelakanginya. Tujuan dari penelitian ini adalah untuk menganalisis pengaruh biaya pendidikan, latar belakang sosial ekonomi, interaksi teman sebaya, motivasi dan reputasi terhadap keputusan mahasiswa memilih jurusan akuntansi. Penelitian ini bertempat di Universitas Pendidikan Ganesha Singaraja. Populasi dalam penelitian ini yakni mahasiswa jurusan akuntansi program s1 universitas pendidikan ganesha angkatan 2013,2014 ,dan 2015. Pengambilan sampel dilakukan dengan teknik simple ramdom sampling, dengan jumlah sampel 400 responden. Jenis data yang digunakan dalam penelitian ini yakni data primer, dengan metode pengumpulan data menggunakan kuisioner. Teknik analisis data menggunakan analisis regresi linier berganda dengan bantuan program SPSS 19 for Windows.

Hasil penelitian menunjukkan bahwa secara parsial terdapat pengaruh signifikan antara latar belakang sosial ekonomi, interaksi teman sebaya, motivasi berprestasi, dan reputasi terhadap keputusan memilih jurusan akuntansi. Biaya pendidikan tidak berpengaruh secara signifikan terhadap keputusan mahasiswa memilih jurusan akuntansi. Secara simultan biaya pendidikan, latar belakang sosial ekonomi, interaksi teman sebaya, motivasi, dan reputasi berpengaruh simultan terhadap keputusan mahasiswa memilih jurusan akuntansi.
\end{abstract}

Kata kunci: biaya pendidikan, latar belakang sosial ekonomi, interaksi teman sebaya, motivasi,reputasi.

Abstract
Increased interest in the accounting department in various universities prove that science today is increasingly popular accounting. It is interesting to discuss, to know the things that lie behind them. The purpose of this study was to analyze the effect of the cost of education, socio-economic background, peer interaction, motivation and reputation against the decision of students choosing accounting majors. This study took place in Singaraja Ganesha Education University. The population in this study that students majoring in accounting education programs s1 university ganesha force 2013.2014 , and 2015 . Sampling was done by simple random sampling technique, with a sample size of 400 respondents. Data used in this study the primary data, the method of data collection using the questionnaire. Data were analyzed using multiple linear regression analysis with SPSS 19 for Windows

The results showed that partially significant effect of socioeconomic background, peer interaction, achievement motivation, and reputation against the decision of selecting the accounting department. The cost of education does not

51 | Arlef Rafsanjan i 
significantly influence the decision of students choosing accounting majors. Simultaneously the cost of education, socio-economic background, peer interaction, motivation, and the reputation of the simultaneous effect of the decision of students choosing accounting majors

Keywords: cost of education, socio-economic background, peer interaction, motivation, reputation.

\section{PENDAHULUAN}

Kemajuan teknologi yang tidak terbatas terjadi setiap waktu di setiap belahan dunia. Pergerakan kemajuan teknologi merupakan suatu tuntutan yang secara otomatis harus dipenuhi untuk memberikan kemudahan bagi setiap orang. Untuk dapat bersaing dan berperan dalam kondisi dunia sekarang ini,pendidikan menjadi syarat mutlak. Pendidikan menjadi sarana untuk mengembangkan pengetahuan dan kemampuan melalui pembelajaran yang diberikan. Perguruan tinggi merupakan jenjang akhir dalam dunia pendidikan yang menjadi salah satu syarat untuk terjun dalam dunia kerja. Pada saat ini akuntansi adalah salah satu program studi berlatar belakang ilmu sosial yang banyak diminati oleh para calon mahasiswa.Jurusan Akuntansi menjadi jurusan favorit diberbagai perguruan tinggi di Indonesia, baik itu perguruan tinggi negeri maupun swasta, salah satunya Universitas Pendidikan Ganesha. Jurusan Akuntansi Program S1 di UNDIKSHA merupakan salah satu jurusan unggulan.

Ditainjau dari sisi mahasiswa, secara umum terdapat banyak terdapat banyak faktor yang melatarbelakangi keputusan mahasiswa untuk memilih jurusan yang ada di perguruan tinggi. Kuliah di suatu universitas bukan lagi dengan tujuan utama mencari ilmu, tapi ada motif lain yang kelak setelah lulus berharap mendapkan pekerjaan yang layak (Martini,2011). Dalam keinginan mahasiswa untuk memilih jurusan akuntansi program s1 faktor minat merupakan salah satu faktor yang berpengaruh dalam pemilihan jurusan akuntansi. Minat berasal dari dalam setiap individu itu sendiri yang merupakan kesadaran seseorang terhadap suatu objek, suatu masalah atau situasi yang mengandung kaitannya dengan dirinya.
Universitas Pendidikan Ganesha merupakan perguruan tinggi yang terdiri dari 7 fakultas dan 2 program studi didalamnya. Dalam Fakultas Ekonomi dan Bisnis terdapat program sarjana ( Manajemen, Akuntansi, dan Ekonomi), dan program vokasi ( D3 Akuntansi dan D3 perhotelan ) dari jurusan di Fakultas Ekonomi dan Bisnis, jurusan akuantansi merupakan jurusan yang paling banyak di minati. Menurut data yang dihimpun dari Jurusan Akuntansi Program S1 didapatkan hasil bahwa dari tahun ketahun terjadi peningkatan mahasiswa yang berminat dalam prodi jurusan akuntansi. Peningkatan mahasiswa yang memilih jurusan akuntansi program s1 tidak hanya bersal dari konsentrasi ilmu sosial namun juga bersal dari ilmu alam.

Agar jurusan akuntansi ini memiliki kualitas lulusan yang baik serta dapat memenuhi tuntutan dunia kerja, maka dibutuhkan input yang memiliki kualitas baik pula. Dalam memenuhi kebutuhan tersebut, maka dibutuhkan mahasiswamahasiswi yang benar-benar memiliki minat dan bakat serta ketertarikan pada jurusan akuntansi juga. Hal tersebut menjadi penting untuk mengidentifikasi faktor-faktor apa saja yang berpengaruh pada mahasiswa-mahasiswi dalam memilih sebuah jurusan.

Drummond (1985) dalam Senitasari (2015) berpendapat bahwa pengambilan keputusan merupakan usaha penciptaan kejadian-kejadian dan pembentukan masa depan (peristiwa pada saat pemilihan dan sesuadahnya). Hakikat pengambilan keputusan adalah memilih dua alternatif atau lebih untuk melakukan suatu tindakan tertentu baik secara pribadi maupun kelompok (Syafaruddin \& Anzizhan, 2014: 45 ).

Menurut Wijaya (2010: 84) biaya pendidikan didefinisikan sebagai semua jenis pengeluaran yang dikeluarkan untuk 


\section{Vol. 4 No. 2 Desember 2016}

menyelenggarakan pendidikan. Berdasarkan hukum ekonomi, dikatakan bahwa manusia ingin mendapatkan keuntungan yang setinggitingginya dengan biaya yang serendah-rendahnya. Mahasiswa tentu akan memilih untuk membayar biaya yang lebih rendah untuk dapat menempuh prodi S1 Akuntansi. Biaya dikeluarkan untuk mendapatkan manfaat di masa depan (Hansen dan Mowen, 2009: 47).

Latar belakang sosial ekonomi didefinisikan sebagai lingkungan sosial dimana seseorang berasal dan juga tingkat ekonomi keluarga orang tersebut. Maslihah (2007) dalam Andriani (2013) mengatakan bahwa istilah status sosial ekonomi menunjukkan pada kedudukan seseorang dalam suatu rangking strata yang tersusun secara hirarkis yang merupakan kerataan tertimbang dari hal yang mempunyai nilai dalan suatu masyarakat yang biasa dikenal sebagai privellege (kekayaan, beserta gaya hidupnya) dan kekuasaan. Untuk melihat kedudukan sosial ekonomi adalah pekerjaan, penghasilan dan pendidikan

Slavin (2008:98) mengungkapkan bahwa lingkungan teman sebaya merupakan suatu interaksi dengan orangorang yang mempunyai kesamaan dalam usia dan status. Dalam berinteraksi seseorang lebih memilih bergabung dengan orang-orang yang mempunyai pikiran, hobi dan keadaan yang sama. Dari beberapa uraian di atas maka dapat disimpulkan bahwa lingkungan teman sebaya merupakan suatu interaksi yang intensif dan cukup teratur dengan orangorang yang mempunyai kesamaan dalam usia dan statusInteraksi tersebut berupa interaksi dengan teman sebaya di lingkungan sekolah maupun di lingkungan tempat tinggal.

Motivasi berprestasi adalah
kecenderungan
berusaha meraih keseorang untuk memiliki orientasi tujuan, aktivitas sukses atau gagal (Atkinson, 1982 dalam Sujarwo, 2009). Menurut Rabideu (2005) motivasi berprestasi sebagai dorongan untuk keunggulan dibanding standarnya sendiri maupun orang lain. Berdasarkan pendapat ini, dapat diambil rumusan 53 | Arlef Rafsanjan i

\section{Ekuitas - Jurnal Pendidikan Ekonomi}

bahwa motivasi berprestasi adalah dorongan yang timbul dari dalam diri individu sehubungan dengan adanya pengharapan bahwa tindakan yang dilakukan merupakan alat untuk mencapai hasil yang baik, bersaing dan mengungguli orang lain, mengatasi rintangan serta memelihara semangat yang tinggi.

Menurut Kuswara (2011: 10) dalam Andriani (2013), reputasi dibangun dengan kerja keras, perjuangan, dan tentunya melalui proses yang panjang, reputasi yang dimaksud adalah integritas dan kredibilitas perguruan tinggi yang bersangkutan.

Terdapat beberapa permasalahan yang perlu dikaji lebih lanjut, yaitu apakah biaya pendidikan berpengaruh terhadap sensitivitas etika auditorkeputusan memilih jurusan akuntansi, latar belakang sosial ekonomi terhadap keputusan memilih jurusan akuntansi, apakah interaksi teman sebaya berpengaruh terhadap keputusan memilih jurusan akuntansi, apakah motivasi berpengaruh terhadap keputusan memilih jurusan akuntansi dan apakah reputasi berpengaruh terhadap keputusan memilih jurusan akuntansi, dan apakah biaya pendidikan, latar belakang sosial ekonomi, interaksi teman sebaya, motivasi dan reputasi berpengaruh simultan terhadap keputusan memilih jurusan akuntansi.

Dalam rangka menjawab permasalahan tersebut, penelitian ini bertujuan untuk membuktikan secara empiris pengaruh biaya pendidikan, latar belakang sosial ekonomi, interaksi teman sebaya, motivasi berprestasi, dan reputasi terhadap keputusan memilih jurusan akuntansi. Berdasarkan tujuan dalam penelitian ini maka ditarik beberapa hipotesis dalam penelitian ini yaitu

$\mathrm{H}_{1}$ :Biaya Pendidikan berpengaruh terhadap keputusan mahasiswa dalam memilih jurusan akuntansi program s1.

$\mathrm{H}_{2}$ : Latar belakang sosial ekonomi berpengaruh terhadap keputusan mahasiswa dalam memilih jurusan akuntansi program s1. 
$\mathrm{H}_{3}$ : Interaksi Teman Sebaya berpengaruh terhadap keputusan mahasiswa dalam memilih jurusan akuntansi program s1.

$\mathrm{H}_{4}$ : Motivasi berpengaruh terhadap pengambilan keputusan mahasiswa dalam memilih jurusan akuntansi program s1.

$\mathrm{H}_{5}$ : Reputasi berpengaruh terhadap keputusan mahasiswa dalam memilih jurusan akuntansi program s1

$\mathrm{H}_{6}$ : Biaya pendidikan,latar belakang sosial ekonomi, interaksi teman sebaya, motivasi, dan reputasi berpengaruh simultan terhadap keputusan mahasiswa memilih jurusan akuntansi program s1.

\section{METODE}

Penelitian ini menggunakan jenis rancangan penelitian kuantitatif dengan mengajukan beberapa pernyataan dalam bentuk kuesioner kepada responden yaitu mahasiswa Jurusan Akuntansi Program S1 Universitas Pendidikan Ganesha yang bertujuan untuk menjawab pernyataan yang berkaitan dengan subyek yang diteliti. Data hasil penelitian dianalisis dengan menggunakan bantuan program SPSS 19. Penelitian ini menggunakan jenis data primer.

Populasi dalam penelitian ini adalah seluruh mahasiswa Jurusan Akuntansi Program S1 Universitas Pendidikan Ganesha. Teknik pengambilan sampel dalam penelitian ini menggunakan tipe proporsive sampling yaitu teknik dimana cara pengambilan sampel dilakukan dengan menetapkan ciri yang sesuai dengan tujuan, yang dimana mahasiswa yang menjadi sampel adalah angkatan 2013, 2014, dan 2015. Berdasarkan penentuan sampel tersebut, jumlah kuesioner yang disebar kepada seluruh mahasiswa Jurusan Akuntansi Program S1 adalah sebanyak 400 kuesioner.

Instrumen dalam penelitian ini menggunakan kuesioner dengan skala likert yang digunakan untuk mengukur biaya pendidikan, latar belakang sosial ekonomi, interaksi teman sebaya, motivasi berprestasi dan reputasi.
Penetapan skor diberikan kepada butir-butir pernyataan penelitian di dalam kuesioner. Skala likert yang digunakan dalam penelitian ini berdimensi empat dengan rentangan nilai 1 sampai dengan 4 dengan asumsi jawaban (1) sangat tidak setuju, (2) tidak setuju, (3) netral/ ragu-ragu, (4) setuju, dan (5) sangat setuju.

Pengujian instrumen yang digunakan dalam penelitian ini meliputi uji statistik deskriptif, uji validitas dan uji reliabilitas. Teknik analisis data dalam penelitian ini menggunakan uji asumsi klasik yaitu uji normalitas, uji multikolinearitas, dan uji heterokedastisitas. Metode pengujian hipotesis menggunakan analisis regresi berganda yaitu uji $t$, uji $F$, dan koefisien determinasi $\left(R^{2}\right)$. Uji hipotesis menggunakan analisis regresi berganda yang digunakan untuk melihat pengaruh beberapa variabel independen terhadap variabel dependen.

\section{HASIL DAN PEMBAHASAN}

Jumlah kuesioner yang disebar dalam penelitian ini adalah sebanyak 400 buah. Namun kuesioner yang kembali sebanyak 400 kuesioner kembali dan 20 kuesioner yang tidak memenuhi syarat untuk diolah sehingga kuesioner yang dapat diolah sebanyak 380 kuesioner dengan menggunakan program SPSS.

Pengujian statistik deskriptif dalam penelitian ini untuk mengetahui besarnya nilai rata-rata, nilai minimum, nilai maximum dan standar deviasi dari masing-masing variable. Hasil yang ditunjukkan ialah hasil yang baik, karena masing-masing variabel memiliki standar deviasi yang jauh lebih kecil dari mean, yang mengindikasikan bahwa penyimpangan data cukup rendah.

Pengujian validitas dalam
penelitian ini dilakukan dengan melakukan korelasi bivariate antara masing-masing skor indikator dengan total skor kontruk dengan bantuan program SPSS 19,0 for windows. Bila korelasi antar masing-masing indikator terhadap skor kontruk menunjukkan hasil yang signifikan, yaitu bernilai $<0,05$ maka indikator dinyatakan valid. Hasilnya 


\section{Vol. 4 No. 2 Desember 2016}

menunjukkan bahwa korelasi antara masing-masing indikator/pertanyaan terdapat total skor konstruk menunjukkan hasil yang signifikan. Jadi dapat disimpulkan bahwa masing-masing indikator variabel adalah valid.

Hasil uji reliabilitas dilihat dari nilai Cronbach's Alpha yang variabel Variabel biaya pendidikan memiliki nilai sebesar 0,823 . Variabel latar belakang sosial ekonomi memiliki nilai sebesar 0,806.

\section{Ekuitas - Jurnal Pendidikan Ekonomi}

Variabel interaksi teman sebaya memiliki nilai sebesar 0,863 . Variabel motivasi berprestasi memiliki nilai sebesar 0,801. Variabel reputasi memiliki nilai sebesar 0,762 . Variabel keputusan memilih jurusan akuntansi memiliki nilai sebesar 0,815 . Sehingga dapat disimpulkan bahwa seluruh butir pertanyaan dalam variabel-variabel tersebut adalah reliabel. Karena seruluh variabel mempunyai nilai Cronbach's

Alpha

0,70

Tabel 1. hasil uji normalitas

One-Sample Kolmogorov-Smirnov Test

\begin{tabular}{llr}
\hline & & $\begin{array}{c}\text { Unstandardized } \\
\text { Residual }\end{array}$ \\
\hline N & & 380 \\
Normal Parameters & Mean &, 0000000 \\
& Std. Deviation & 1,50577243 \\
Most Extreme Differences & Absolute &, 063 \\
& Positive &, 029 \\
& Negative &,- 063 \\
Kolmogorov-Smirnov Z & & 1,234 \\
Asymp. Sig. (2-tailed) & &, 095 \\
\hline
\end{tabular}

a. Test distribution is Normal.

Sumber: data primer diolah,2016

Uji normalitas dilakukan untuk mengetahui apakah dalam setiap variabel pernyataan yang digunakan dalam penelitian terdistribusi normal atau tidak.Berdasarkan hasil uji Kolmogrov-
Smirnov dengan nilai Asymp. Sig sebesar $0,995>0,05$ maka dapat dinyatakan bahwa data-data penelitian telah terdistribusi normal.

Tabel 2. hasil uji multikolinearitas

\begin{tabular}{|c|c|c|c|c|}
\hline No & Variabel & Tolerance & VIF & Keterangan \\
\hline 1 & $\begin{array}{c}\text { Biaya pendidikan } \\
\text { (X1) }\end{array}$ & 0,872 & 1.146 & $\begin{array}{c}\text { Tidak terjadi } \\
\text { multikolinearitas }\end{array}$ \\
\hline 2 & $\begin{array}{l}\text { Latar Belakang } \\
\text { Sosial Ekonomi } \\
\text { (X2) }\end{array}$ & 0,826 & 1.210 & $\begin{array}{c}\text { Tidak terjadi } \\
\text { multikolinearitas }\end{array}$ \\
\hline 3 & $\begin{array}{c}\text { Interaksi Teman } \\
\text { Sebaya (X3) }\end{array}$ & 0,893 & 1.119 & $\begin{array}{c}\text { Tidak terjadi } \\
\text { multikolinearitas }\end{array}$ \\
\hline 4 & $\begin{array}{c}\text { Motivasi } \\
\text { Berprestasi (X4) }\end{array}$ & 0,868 & 1,151 & $\begin{array}{c}\text { Tidak terjadi } \\
\text { multikolinearitas }\end{array}$ \\
\hline 5 & Reputasi (X5) & 0,926 & 1,080 & $\begin{array}{c}\text { Tidak terjadi } \\
\text { multikolinearitas }\end{array}$ \\
\hline
\end{tabular}

Sumber: data primer diolah

Hasil perhitungan uji multikolinearitas menunjukkan bahwa nilai tolerance variabel bebas lebih besar dari 0,1 dan nilai VIF lebih kecil dari 10 sehingga dapat disimpulkan tidak terjadi multikolinearitas

Tabel 3. Hasil uji heteroskedastisitas 
Ekuitas - Jurnal Pendidikan Ekonomi

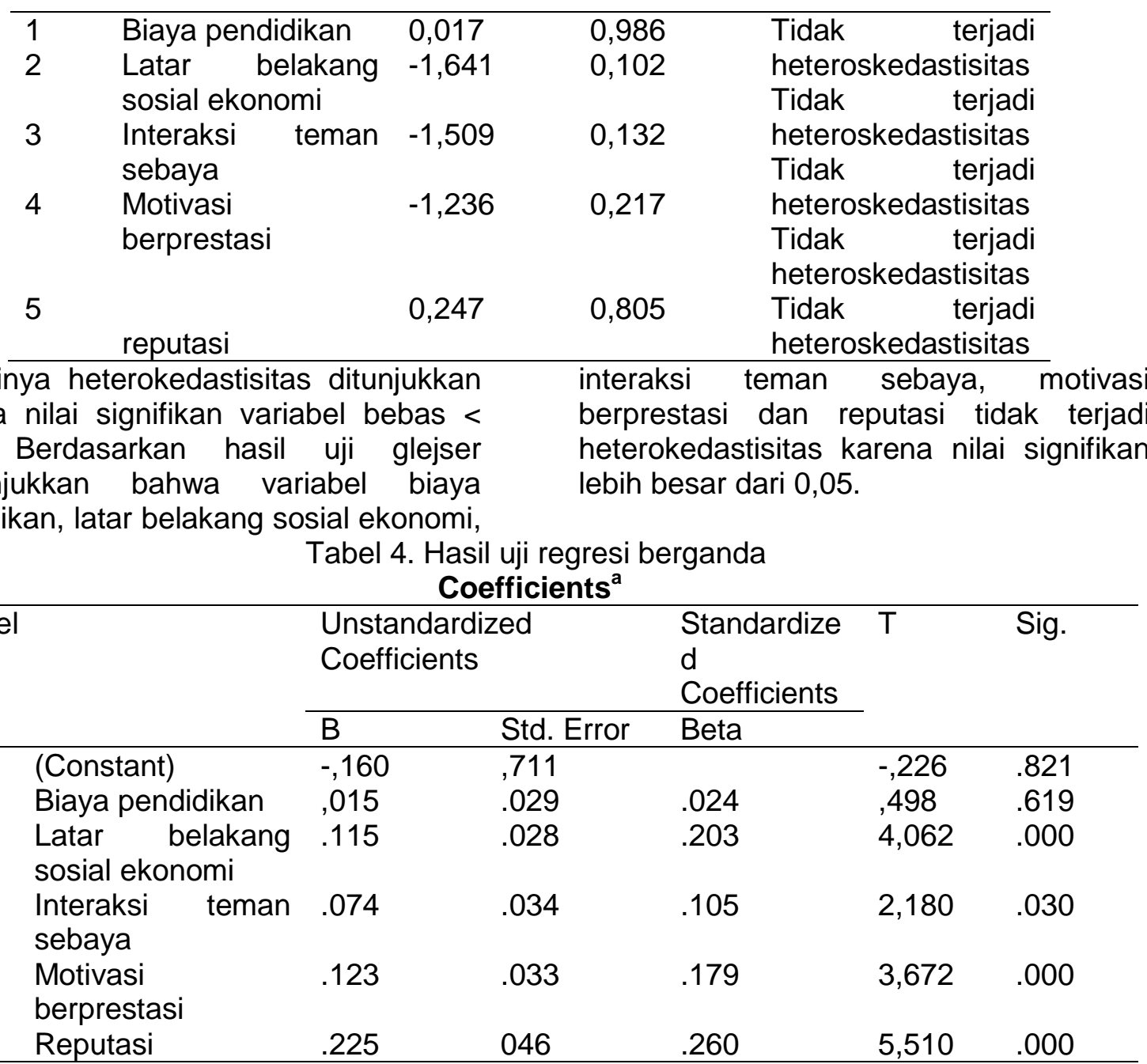

a. Dependent Variable: Keputusan Memilih Jurusan Akuntansi

Berdasarkan hasil uji hipotesis dengan menggunakan analisis regresi linier berganda memperoleh persamaan sebagai berikut: $\mathrm{Y}=-0.160+0,015 \mathrm{BP}+$ 0,115 LB + 0,074 ITS + 0,123 MB+ 0,255 $\mathrm{R}+\varepsilon$. Koefisien regresi Biaya Pendidikan sebesar 0.015 berarti bahawa apabila terdapat penambahan biaya pendidikan sebesar 1 satuan, maka keputusan memilih jurusan akuntansi akan meningkat sebsar 0,015. Koefisien regresi Latar Belakang Sosial Ekonomi sebesar 0.115 berarti bahawa apabila terdapat penambahan latar belakang sosial ekonomi sebesar 1 satuan, maka keputusan memilih jurusan akuntansi akan meningkat sebsar 0,115 .
Koefisien regresi Interaksi Teman Sebaya sebesar 0.074 berarti bahawa apabila terdapat penambahan interaksi teman sebaya sebesar 1 satuan, maka keputusan memilih jurusan akuntansi akan meningkat sebsar 0,074 . Koefisien regresi Motivasi Berprestasi sebesar 0.123 berarti bahawa apabila terdapat penambahan motivasi berprestasi sebesar 1 satuan, maka keputusan memilih jurusan akuntansi akan meningkat sebsar 0,123. Koefisien regresi Reputasi sebesar 0.225 berarti bahawa apabila terdapat penambahan reputasi sebesar 1 satuan, maka keputusan memilih jurusan akuntansi akan meningkat sebsar 0,225 dengan asumsi variabel lain bernilai tetap.

Tabel 5. hasil pengujian koefisien determinasi 


\begin{tabular}{|c|c|c|c|c|}
\hline \multicolumn{5}{|c|}{ Model Summary } \\
\hline Model & $\mathrm{R}$ & R Square & $\begin{array}{l}\text { Adjusted } \\
\text { Square }\end{array}$ & $\begin{array}{l}\text { R Std. Error of } \\
\text { the Estimate }\end{array}$ \\
\hline 1 &, $480^{a}$ & ,230 & .220 & 1,516 \\
\hline
\end{tabular}

a. Predictors: (Constant), reputasi, biaya

pendidikan,interaksi teman sebaya, motivasi berprestasi,

latar belakang sosial ekonomi

Tabel tersebut menunjukkan bawha $R^{2}$ adalah sebesar 0,22 yang berarti variabel keputusan memilih jurusan akuntansu dapat dijelaskan oleh variabel biaya pendidikan, latar belakang sosial

ekonomi, interaksi teman sebaya, motivasi berprestasi dan reputasi sebesar $22 \%$, Sedangkan sisanya sebesar $88 \%$ dijelaskan oleh variabel-variabel lain diluar modelpenelitian.

Tabel 6. hasil perhitungan Uji $\mathrm{F}$

\begin{tabular}{|c|c|c|c|c|c|c|}
\hline \multicolumn{7}{|c|}{ ANOVA $^{b}$} \\
\hline \multicolumn{2}{|l|}{ Model } & $\begin{array}{l}\text { Sum } \\
\text { Squares }\end{array}$ & of & Mean & & Siq \\
\hline \multirow[t]{3}{*}{1} & Regression & 256,611 & 5 & 51,322 & 22,337 & $.000^{\mathrm{a}}$ \\
\hline & Residual & 859,326 & 374 & 2,298 & & \\
\hline & Total & 1115,937 & 379 & & & \\
\hline
\end{tabular}

a. Predictors: (Constant), reputasi, biaya pendidikan, latar belakang sosial ekonomi, interaksi teman sebaya,motivasi berprestasi

b. Dependent Variable: keputusan memilih jurusan akuntansi tingkat

Berdasarkan tabel diatas diperoleh $F_{\text {hitung }}$ sebesar 22,337 $>F_{\text {tabel }}$ 2,238 dengan

signifikansi $p$ value lebih kecil dari 0,05 yaitu 0,000 . Dengan begitu dapat disimpulkan bahwa variabel keputusan memilih jurusan akuntansi dapat dipengaruhi oleh biaya pendidikan, latar belakang sosial ekonomi, interaksi teman sebaya, motivasi berprestasi, danreputasi.

\footnotetext{
Hasil uji $\mathrm{t}$ pada tabel 4, biaya pendidikan $\quad t_{\text {hitung }}<t_{\text {tabel }} \quad$ sebesar $0,498<1,966$ dan nilai signifikan sebesar 0,619 yang berarti lebih besar dari 0,05. Hal tersebut menunjukkan biaya pendidikan tidak berpengaruh secara signifikan terhadap keputusan memilih jurusan akuntansi. Untuk variabel latar belakang sosial ekonomi $t_{\text {hitung }}<t_{\text {tabel }}$ sebesar 4,062 $<1,966$ dan nilai signifikan sebesar 0,000 yang berarti lebih kecil dari 0,05 . Hal tersebut menunjukkan latar belakang sosial ekonomi berpengaruh signifikan terhadap keputusan memilih jurusan akuntansi. Variabel interaksi teman sebaya $t_{\text {nitung }}<t_{\text {tabel }} \quad$ sebesar $2,180<1,966$ dengan nilai signifikan 0,30 yang lebih kecil dari 0,05 . Hal ini menunjukkan interkasi teman sebaya 57| Arlef Rafsanjan i
}

berpengaruh signifikan terhadap keputusan memilih jurusan akuntansi. Untuk variabel motivasi berprestasi, $t_{\text {hitung }}<t_{\text {tabel }}$ sebesar $3,672<1,966$ dan signifikan 0,000 yang lebih kecil dari 0,05 yang menunjukkan motivasi berprestasi berpengaruh secara signifikan terhadap keputusan mahasiswa memilih jurusan akuntansi. Untuk variabel reputasi, $t_{\text {hitung }}<t_{\text {tabel }}$ sebesar 5,510<1,966 dan signifikan sebasar 0,00 lebih kecil dari 0,05 yang menunjukkan bahwa reputasi berpengaruh secara signifikan terhadap keputusan mahasiswa memilih jurusan akuntansi

\section{PEMBAHASAN}

Pengaruh Biaya Pendidikan terhadap
Keputusan Memilih Jurusan Akuntansi Hasil pengujian hipotesis pertama menunjukkan bahwa variabel biaya pendidikan tidak berpengaruh secara signifikan terhadap keputusan mahasiswa memilih jurusan akuntansi yang ditunjukkan oleh nilai (sig.) $t$ sebesar 0,619 , yang dimana tingkat signifikansi variabel pengalaman lebih besar dari 0,05 
yang berarti hipotesis tidak diterima. Hal ini berarti bahwa variabel biaya pendidikan tidak berpengaruh terhadap keputusan mahasiswa memilih jurusan akuntansi. Hal ini dikarenakan mahasiswa beranggapan bahwa uang kuliah tunggal bukan merupakan pertimbangan untuk memilih jurusan akuntansi. Selain itu, adanya pembebanan biaya perkullaiahn lainnya seperti biaya yang menunjang perkuliahan dan adanya pungutan uang HMJ yang tinggi harus ditanggung oleh mahasiswa tidak semerta menjadi alasan mahasiswa memilih jurusan akuntansi dan terlebih lagi adanya fasilitas wifi yang disediakan oleh jurusan yang mendukung perkuliahan tidak dipergunakan secara maksimal. Selain itu, adanya program beasiswa yang meringankan biaya mahasiswa selama menempuh pendidikan di Jurusan Akuntansi Program S1 di Universitas Pendidikan Ganesha mengakibatkan biaya pendidikan yang harus ditanggung menjadi lebih sedikit.

\section{Pengaruh Latar belakang sosial ekonomi terhadap keputusan mahasiswa memilih jurusan akuntansi}

Hasil pengujian hipotesis kedua menunjukkan bahwa latar belakang sosial ekonomi berpengaruh positif terhadap keputusan mahasiswa memilih jurusan akuntansi. Hasil analisis menunjukkan (sig.) t sebesar 0,000, yang dimana tingkat signifikansi variabel komitmen profesional sebesar 0,000 lebih kecil dari 0,05 yang artinya hipotesis diterima. Hal tersebut menunjukkan bahwa latar belakang sosial ekonomi berpengaruh positif terhadap keputusan memilih jurusan akuntansi.

Hal ini didukung oleh penjelasan tentang Latar belakang sosial ekonomi didefinisikan sebagai lingkungan sosial dimana seseorang berasal dan juga tingkat ekonomi keluarga orang tersebut. Berdasarkan Lestarini (2008) dalam Senitasari (2015), tinggi rendahnya status sosial ekonomi seseorang ditentukan oleh pendidikan, pekerjaan, dan penghasilan.

Akuntansi merupakan program pendidikan yang digemari, dilihat dari banyaknya mahasiswa akuntansi diberbagai perguruan tinggi. Dengan

58| Arlef Rafsanjan i memilih jurusan favorit diperguruan tinggi. Berdasarkan teori tersebut, nampak bahwa pengambilan keputusan dipengaruhi oleh latar belakang sosial ekonomi yang dimiliki seseorang. Hal ini juga didukung oleh adanya pendapatan dari oarang tua, latar belakang pendidikan orang tua, profesi orang tua serta adanya latar belakang lingkungan sosial yang menjadi salah satu alasan mahasiswa memilih jurusan akuntansi, dikarena kecendrungan oleh seorang pribadi yang ingin memiliki kedudukan yang sama seperti yang dimiliki oleh lingkungan sosialnya.

\section{Pengaruh Interaksi teman sebaya terhadap keputusan memilih jurusan akuntansi}

Hasil pengujian hipotesis yang ketiga menunjukkan bahwa budaya etis organisasi berpengaruh positif terhadap sensitivitas etika pada auditor kantor akuntan publik di Bali. Hal ini ditunjukkan oleh dimana tingkat signifikansi 0,030 lebih kecil dari 0,05 yang artinya hipotesis diterima.

Slavin (2008:98) mengungkapkan bahwa lingkungan teman sebaya merupakan suatu interaksi dengan orangorang yang mempunyai kesamaan dalam usia dan status. Dalam berinteraksi seseorang lebih memilih bergabung dengan orang-orang yang mempunyai pikiran, hobi dan keadaan yang sama. Dari beberapa uraian di atas maka dapat disimpulkan bahwa lingkungan teman sebaya merupakan suatu interaksi yang intensif dan cukup teratur dengan orangorang yang mempunyai kesamaan dalam usia dan status. Interaksi tersebut berupa interaksi dengan teman sebaya di lingkungan sekolah maupun di lingkungan tempat tinggal.

Berdasarkan konsep yang ada, tampak bahwa interaksi teman sebaya sangat berpengaruh terhadap keputusan memilih jurusan akuntansi. Faktor teman dalam setiap keputusan memang memberikan pengaruh, baik secara langsung maupun tidak secara langsung. Hal ini tentu saja menggambarkan bahwa teman mempengaruhi setiap keputusan seorang individu. Keputusan yang diambil 


\section{Vol. 4 No. 2 Desember 2016}

dengan pertimbangan dan saran dari seorang teman. Dalam proses perkuliahan teman merupakan sebuah pertimbangan yang dapat dibilang penting karena dalam pengambilan keputusan mahasiswa selalu mengedepankan sebuah masukan dari seorang teman.

\section{Pengaruh motivasi terhadap keputusan memilih jurusan akuntansi}

Hasil pengujian hipotesis keempat menunjukkan bahwa motivasi berprestasi berpengaruh terhadap keputusan memilih jurusan akuntansi. Hal ini ditunjukan oleh nilai tingkat signifikansi 0,000 lebih kecil dari 0,05 yang artinya hipotesis diterima.

McClelland (1987) mendefinisikan motivasi berprestasi sebagai motivasi yang mendorong individu untuk mencapai sukses, dan bertujuan untuk berhasil dalam kompetisi atau persaingan dengan beberapa ukuran keunggulan (standard of excelence). Ukuran keunggulan itu dapat berupa prestasi sendiri sebelumnya atau prestasi orang lain. Motivasi berprestasi sebagai keinginan untuk mencapai prestasi sesuai dengan standard yang telah ditetapkan (Degeng, 1997). Adanya keinginan berprestasi, adanya rasa senang mengerjakan tugas yang menantang, senang belajar mandiri dan adanya rasa berkompetisi antar mahasiswa merupakan salah satu alasan bagi mahasiswa untuk memilih jurusan akuntansi.

\section{Pengaruh reputasi terhadap keputusan mahasiswa memilih jurusan akuntansi.}

Hasil pengujian hipotesis kelima dalam penelitian ini menunjukkan bahwa variabel reputasi berpengaruh terhadap keputusan memilih jurusan akuntansi. Hal ini ditunjukkan dengan tingkat signifikansi lebih kecil dari 0,05 yaitu 0,000 yang artinya hipotesis diterima.

Reputasi biasanya dikenal dengan istilah nama baik. Semakin baik reputasi sesuatu, maka semakin tinggi juga respect/penghargaan yang diberikan orang terhadap hal tersebut. Menurut Kuswara (2011: 10) dalam Andriani (2013), reputasi dibangun dengan kerja keras, perjuangan, dan tentunya melalui proses yang panjang, reputasi yang

\section{Ekuitas - Jurnal Pendidikan Ekonomi}

dimaksud adalah integritas dan kredibilitas perguruan tinggi yang bersangkutan.

Terakreditasnya Jurusan Akuntansi Program S1 di Universitas Pendidikan Ganesha yang didukung oleh dosen pengajar yang berpengalaman serta suasana akademis yang dilihat dari kualitas proses pembelajaran yang memadai menjadi alasan bagi mahasiswa dalam mengambil keputusan memilih jurusan akuntansi. Berdasarkan teori yang ada, nampak bahwa motivasi memiliki pengaruh dan berbanding lurus dengan pengambilan keputusan.

\section{Pengaruh biaya pendidikan, latar belakang sosial ekonomi, interaksi teman sebaya, motivasi, dan reputasi terhadap keputusan memilih jurusan akuntansi.}

Hasil peneletian hipotesis keenam yang ditunjukkan pada tabel 6 , diproleh $F_{\text {hitung }}>F_{\text {tabel }}$ sebesar 22,337>2,238 dengan tingkat signifikan lebih kecil dari 0,05 yaitu 0,00 . Dengan demikian dapat disimpulkan bahwa variabel keputusan memilih jurusan akuntansi dipengaruhi secara simultan oleh biaya pendidikan, latar belakang sosial ekonomi, interaksi teman sebaya, motivasi, dan reputasi.

Berdasarkan teori yang ada. Biaya pendidikan yang merupakan segala bentuk pengeluaran untuk meneyelenggarakan pendidikan (Wijaya:2010, 84). Dengan adanya hasrat manusia yanbng ingin mendapatkan keuntungan yang tinggi dengan biaya serendah-rendahnya, mahasaiwa tentu akan memilih untuk membayar biaya yang lebih rendah untuk menempuh prodi $s 1$ akuntansi. Selain itu, latar belakang sosial ekonomi yang melatarbelakangi mahasiswa dalam memilih jurusan akuntansi untuk menunjukkan kedudukan seseorang dalam rangking strata byang tersusun secara hirarki yang merupakan kerataan tertimbang dari hal yang mempunyai nilai dalam suatu masyarakat yang biasa dikenal sebagai privellge dan kekuasaan. Lingkungan teman sebaya yang merupakan suatu interaksi orangorang yang mempunyai kesamaan dalan usia dan status. Ini yang mempengaruhi seseorang dalam menentukan pilihannya. 


\section{Vol. 4 No. 2 Desember 2016}

Selain itu juga, reputasi dari suatu universitas dan jurusan memberikan nilai lebih dan menjadi tolak ukur dari seseorang untuk menentukan pilihan. Faktor internal yang mempengaruhi keputusan mahasiswa memilih jurusan ialah motivasi yang merupakan dorongan baik dari dalam maupun luar untuk mencapai tujuan yang telah ditetapkan.

\section{SIMPULAN DAN SARAN Simpulan}

Berdasarkan hasil penelitian seperti yang telah diuraikan sebelumnya, maka dapat ditarik beberapa kesimpulan sebagai berikut: (1) biaya pendidikan tidak berpengaruh secara signifikan terhadap keputusan memilih jurusan akuntansi, (2) latar belakang sosial ekonomi berpengaruh secara signifikn terhadap keputusan memilih jurusan akuntansi, (3) interaksi teman sebaya berpengaruh secara signifikan terhadap keputusan memilih jurusan akuntansi, (4) motivasi berpengaruh secara Signifikan terhadap keputusan memilih jurusan akuntansi, (5) reputasi berpengaruh terhadap keputusan memilih jurusan akuntansi.(6) biaya pendidikan, latar belakang sosial ekonommi, interaksi teman sebaya, motivasi dan reputasi berpengaruh secara imultan terhadap keputusan mahasiswa memilih jurusan akuntansi.

\section{Saran}

Berdasarkan kesimpulan hasil penelitian, dapat disampaikan beberapa saran sebagai berikut:

1. Bagi pengelola jurusan akuntansi program s1 universitas pendidikan ganesha lebih meningkatkan efektivitas perkuliahan dan memberikan pelatihan berupa pratikum, melihat motivasi berprestasi dan reputasi menjadi salah satu alasan mahasiswa memilih jurusan ini.

2. Bagi peneliti selanjutnya dapat memperbanyak variabel independen selain biaya

Slavin, Robert E. 2008. Psikologi Pendidikan Teori dan Praktik. Jakarta: PT Indeks.

Sugiyono. 2010. Metode penelitian bisnis. Bandung: CV alvabeta

\section{Ekuitas - Jurnal Pendidikan Ekonomi}

pendidikan, latar belakang sosial ekonomi, interaksi teman sebaya, motivasi dan reputasi, seperti fasilitas kampus, kemampuan dosen serta memperbanyak indikator variabel. Selain itu dapat pula menambah metode lainnya, seperti metode wawancara untuk menambah kuat metode kuisioner.

\section{DAFTAR PUSTAKA}

Andriani, Evanti. 2013. Pengaruh Biaya Pendidikan, Latar Belakang Sosial Ekonomi, Motivasi Dan Reputasi Terhadap Minat Mahasiswa Dalam Memilih Prodi S1 Akuntansi Perguruan Tinggi Di Malang. Jurnal Ilmiah Mahasiswa FEB. Vol. 1 No. 2, 2013. Malang. Universitas Brawijaya.

Chaplin, J.P. 2002. Kamus Psikologi. Jakarta: Rajawali Pers

Ghozali, Imam. 2011. Aplikasi Analisis Multivariat Dengan Program SPSS. Semarang: Badan Penerbit Universitas Diponogoro.

Jususp, Haryono. 2005. Dasar-Dasar Akuntansi. Edisi Keenam. Yogyakarta: Sekolah Tinggi IImu Ekonomi YKPN.

Martini. 2011. Analisis Faktor-Faktor Yang Mempengaruhi Pemilihan Jurusan Akuntansi Sebagai Tempat Kuliah Di Perguruan Tinggi. Fakultas Ekonomi Universitas Budi Luhur, Jakarta.

McClelland,D.C.1987. Human Motivation. New york: The Press Syndicate of The University of Chambridge

Senitasari, Winda. 2015. Pengaruh Latar Belakang Sosial Ekonomi, Biaya Pendidikan, Peluang Kerja Dan Motivasi Terhadap Keputusan Mahasiswa Dalam Memilih Jurusan Akuntansi Program S1 Di Universitas Pendidikan Ganesha. Skripsi. Universitas Pendidikan Ganesha. --. 2013. Metode Penelitian Kuantitatif Dan $R$ \& D. Cetakan Ke Delapan Belas. Bandung: CV Akfabeta 
Vol. 4 No. 2 Desember 2016

Sujarwo.2011. Motivasi Berprestasi Sebagai Salah satu perhatian dalam memilih startegi pembelajaran. Skripsi. UNY

Syafaruddin dan anzizhan. 2004. Sistem Pengambilan

\section{Ekuitas - Jurnal Pendidikan Ekonomi}

Pendidikan. Jakarta: Penerbit PT Grindo

Wibowo, Alexander.2014. Kinerja Riset Universitas, Reputasi Universitas, Dan Pilihan Universitas: Sebuah Telaah Sistematis. Jurnal manajemen. vol 13 No 2 Hal. 81-152 